\title{
Analisis Kesalahan Siswa dalam Menyelesaikan Soal Matematika Pada Materi Himpunan Kelas VII SMP/MTs
}

\author{
Jannatul Aulia ${ }^{1}$, Kartini $^{2}$ \\ ${ }^{1,2}$ Pascasarjana Pendidikan Matematika, Fakultas Keguruan dan Ilmu Pendidikan, Universitas Riau, \\ Kampus Bina Widya Km 12,5 Simpang Baru, Pekanbaru, Indonesia \\ jannatul.aulia1988@grad.unri.ac.id
}

\begin{abstract}
This research was motivated by the many difficulties experienced by students during the mathematics learning process which has an impact on the occurrence of errors in doing math problems. These mistakes need to be known to make it easier to find solutions and which parts need to be emphasized in learning, so that these mistakes can be minimized. This research is a descriptive qualitative study that aims to analyze and describe the types of errors that students make in solving math problems on the set material. The subjects of this study were 10 grade VII students of the odd semester of the 2020/2021 school year at MTsS Mahadurrokan Sekeladi in Rokan Hilir. The data collection technique is in the form of a written test. From the results of the student error analysis, it was found that the percentage of errors made by students was: 1) conceptual error of $68.9 \%$ with the error rate being in the "High" criterion; 2) procedural error of $11.1 \%$ with an error rate of "Very low"; 3 ) technical error of $20.0 \%$ with a "Low" error rate. It can be concluded that students 'understanding of the concept of the set is still relatively low, the teacher needs to pay attention to students' knowledge of the concept of set material and to emphasize students regarding the important parts used in the concept of the set.
\end{abstract}

Keywords: Error Analisys, set.

\begin{abstract}
Abstrak
Penelitian ini dilatarbelakangi oleh banyaknya kesulitan yang dialami siswa pada saat proses belajar matematika yang berdampak pada terjadinya kesalahan dalam mengerjakan soal-soal matematika. Kesalahankesalahan ini perlu diketahui agar lebih mudah mencari solusi dan bagian mana saja yang perlu ditekankan dalam pembelajaran, sehingga kesalahan-kesalahan tersebut dapat diminimalisir. Penelitian ini merupakan penelitian kualitatif deskriptif yang bertujuan menganalisis dan mendeskripsikan jenis kesalahan yang dilakukan siswa dalam menyelesaikan soal matematika pada materi Himpunan. Subjek penelitian ini adalah 10 orang siswa kelas VII semester ganjil tahun pelajaran 2020/2021 di MTsS Mahadurrokan Sekeladi di Rokan Hilir. Teknik pengumpulan data berupa tes tertulis. Dari hasil analisis kesalahan siswa, diperoleh persentase kesalahan yang dilakukan siswa ialah: 1) kesalahan konseptual sebesar 68,9\% dengan tingkat kesalahan berada pada kriteria "Tinggi"; 2) kesalahan prosedural sebesar 11,1\% dengan tingkat kesalahan "Sangat rendah"; 3) kesalahan teknis sebesar $20.0 \%$ dengan tingkat kesalahan "Rendah". Sehingga dapat disimpulkan bahwa pemahaman konsep siswa terhadap konsep himpunan masih tergolong rendah, guru perlu memperhatikan pengetahuan siswa akan konsep materi himpunan serta memberikan penekanan terhadap siswa mengenai bagian-bagian penting yang digunakan dalam konsep himpunan.
\end{abstract}

Kata kunci: Analisis kesalahan siswa, himpunan.

Copyright (c) 2021 Jannatul Aulia, Kartini

$\triangle$ Corresponding author: Kartini

Email Address: kartini@lecturer.unri.ac.id (Kampus Bina Widya Km 12,5 Simpang Baru, Pekanbaru, Indonesia)

Received 02 Februari 2021, Accepted 16 Maret 2021, Published 16 Maret 2021

\section{PENDAHULUAN}

Matematika merupakan salah satu bidang studi yang selalu digunakan untuk menyelesaikan suatu permasalahan dalam kehidupan sehari-hari. Dalam pelaksanaan pendidikan, pelajaran matematika diberikan kepada semua jenjang pendidikan dimulai dari sekolah dasar sampai di perguruan tinggi (Listiana \& Sutriyono, 2018). Keberhasilan dalam pendidikan dapat diukur dari keberhasilan dalam proses belajar mengajar (Wibawa, 2017). Salah satu peran yang sangat penting dalam keberhasilan pelaksanaan pendidikan ialah guru. Guru berperan dalam menciptakan kondisi belajar mengajar yang mampu mengantarkan siswa memperoleh kompetensi yang sudah ditetapkan 
(Hidayat \& Pujiastuti, 2019). Agar kompetensi yang sudah ditetapkan dapat tercapai dalam proses pengajaran matematika, seorang guru perlu mengetahui dan mengindentifikasi apa saja yang menjadi kesulitan siswa terhadap materi matematika yang diajarkan (Haryadi \& Nurmaningsih, 2019).

Kesulitan belajar dalam mata pelajaran matematika memiliki karakteristik tersendiri apabila dibandingkan dengan kesulitan belajar dalam mata pelajaran yang lain, diantaranya ialah kesulitan membedakan angka, simbol-simbol matematika dan tidak sanggup mengingat dalil-dalil matematika (Ratnasari \& Setiawan, 2007). Salah satu materi matematika yang sering dijumpai kesulitan oleh siswa dalam menyelesaikan soal ialah materi Himpunan. Sub materi Himpunan yang diajarkan di kelas VII SMP/MTs berdasarkan kurikulum 2013 ialah pengertian himpunan, himpunan bagian, himpunan semesta, himpunan kosong, komplemen himpunan, operasi himpunan, diagram Venn dan menyelesaikan masalah kontekstual dengan menggunakan konsep himpunan (Mursalina et al., 2019). Materi himpunan memiliki tingkat kesulitan yang cukup tinggi terutama pada jenis soal cerita (Dwidarti et al., 2019). Soal cerita merupakan karakteristik dasar materi himpunan dalam pemecahan masalah yang membutuhkan pemahaman konsep untuk dapat mengidentifikasi dan menyelesaikan masalah yang diberikan (Amelia et al., 2016).

Dalam pembelajaran di kelas seringkali dijumpai beberapa siswa yang mengalami kesulitan belajar pada materi himpunan yang disebabkan oleh ketidak-pahaman siswa terhadap konsep himpunan. Seperti yang diungkapkan dalam penelitian terdahulu yang dilakukan oleh Fauza et al. (2017) menjelaskan bahwa diantara kesalahan yang dilakukan siswa pada materi himpunan ialah: kesalahan dalam mendaftarkan anggota himpunan, kesalahan dalam menentukan notasi himpunan, dan kesalahan dalam merepresentasikan hubungan antarhimpunan ke dalam diagram venn. Lebih lanjut, Eksan (dalam Natsir et al., 2016) menyatakan bahwa kesulitan yang dijumpai siswa ialah kesulitan dalam menyatakan masalah sehari-hari kedalam bentuk himpunan dan menyatakan anggotanya, sulit menentukan mana yang termasuk himpunan dan mana yang bukan himpunan sehingga terjadi kesalahan dalam menyelesaikan permasalahan yang diberikan.

Menurut Sulistio et al. (2019) kesalahan adalah penyimpangan dari sesuatu yang benar. Ulifa (dalam Ningsih et al., 2019) menyatakan bahwa kesalahan merupakan suatu bentuk penyimpangan terhadap hal benar, prosedur yang telah ditetapkan sebelumnya, atau penyimpangan dari suatu yang diharapkan. Lebih lanjut, menurut Mauliandri \& Kartini (2020) kesalahan merupakan penyimpangan yang dilakukan dalam menyelesaikan suatu pekerjaan yang telah ditetapkan sebelumnya. Sehingga dapat dikatakan bahwa kesalahan merupakan penyimpangan yang dilakukan seseorang dalam menyelesaikan suatu pekerjaan dikarenakan tidak sesuai dengan aturan atau ketetapan yang ada.

Hamzah (dalam Yuanita \& Solfitri, 2014) menyatakan bahwa ketidakmampuan siswa menyelesaikan masalah akan berakibat terjadinya kesalahan dalam menyelesaikannya. Jika salah satu langkah penyelesaian terdapat kesalahan, maka akan menyebabkan kesalahan pada langkah selanjutnya. Menurut Adilistiyo \& Slamet (2017) kesalahan siswa dalam mengerjakan soal dapat menjadi petunjuk untuk mencari faktor-faktor penyebab yang mempengaruhi rendahnya prestasi 
belajar. Dengan ditemukannya faktor-faktor tersebut dapat digunakan untuk meminimalisasi kesalahan-kesalahan yang dilakukan oleh siswa dalam mengerjakan soal matematika.

Kesalahan yang dilakukan oleh siswa dapat disebabkan oleh beberapa faktor, baik faktor dari dalam diri maupun faktor dari luar. Menurut Lyan dan Kahar (dalam Raharti \& Yunianta, 2020) faktor dari dalam diri dapat berupa kurangnya motivasi, kurang minat siswa terhadap materi tersebut, bakat siswa tidak dalam pelajaran matematika, pola pikir siswa sudah menganggap matematika itu sulit dan lain sebagainya. Faktor dari luar diri biasanya kondisi lingkungan belajar, teman yang malas, dukungan keluarga dan lainnya. Ika (dalam Nurdiawan \& Zanthy, 2019) menjelaskan secara lebih spesifik faktor atau penyebab terjadinya kesalahan yang sering dilakukan oleh siswa dalam menyelesaikan soal-soal matematika antara lain adalah kurangnya pemahaman atas materi prasyarat maupun materi pokok yang dipelajari, kurangnya penguasaan bahasa matematika, keliru menafsirkan atau menerapkan rumus, salah perhitungan, kurang teliti, dan lupa konsep.

Ada beberapa jenis kesalahan dalam belajar matematika. Salah satunya jenis kesalahan menurut Kiat (2005) yang mengklasifikasikan kesalahan menjadi tiga kategori, yaitu :1) Kesalahan konseptual, yaitu mengacu pada kesalahan karena kegagalan untuk memahami konsep yang terlibat dalam masalah atau kesalahan yang muncul dari kegagalan untuk menghargai hubungan yang terlibat dalam masalah; 2) Kesalahan prosedural, yaitu kesalahan yang muncul dari kegagalan untuk melakukan manipulasi atau algoritma meskipun telah memahami konsep di balik masalah; 3) Kesalahan teknis, yaitu mengacu pada kesalahan karena kurangnya pengetahuan konten matematika dalam topik lain atau kesalahan karena kecerobohan.

Sulistyaningsih \& Rakhmawati (2017) menyatakan bahwa kesalahan menurut Kastolan dalam menyelesaikan soal matematika juga dibagi menjadi 3 jenis, yaitu kesalahan konseptual, kesalahan prosedural, dan kesalahan teknik. Kastolan (dalam Lenterawati et al., 2018) menjelaskan bahwa dikategorikan kesalahan konseptual apabila siswa tidak menggunakan rumus dengan benar. Kesalahan prosedural jika langkah yang digunakan kurang tepat sehingga masih menjadi bentuk yang belum sederhana. Dan dikategorikan kesalahan teknik jika kurang teliti dalam perhitungan atau kesalahan penulisan. Perbedaanya dengan Kiat ialah terletak pada kategori kesalahan yang ketiga. Kiat menggunakan istilah kesalahan teknis selain untuk mengkategorikan kesalahan karena kecerobohan juga disertai kesalahan yang terjadi dikarenakan kurangnya pengetahuan konten matematika dalam topik lain.

Berdasarkan kesalahan-kesalahan tersebut, peneliti tertarik untuk mengidentifikasi kesalahankesalahan yang dilakukan siswa dalam menyelesaikan soal-soal tentang materi himpunan. Jenis kesalahan yang dilakukan siswa akan dianalisis dan dideskripsikan berdasarkan jenis kesalahan konseptual, prosedural dan teknis. Tujuan dari penelitian ini adalah untuk mengetahui seberapa besar persentase dan tingkat kesalahan konseptual, prosedural dan teknis yang dilakukan siswa dalam menyelesaikan soal metematika pada materi himpunan sehingga dapat dicari solusinya dan bagian apa saja yang pelru penekanan yang lebih mendalam ketika proses pembelajaran himpunan. 


\section{METODE}

\section{Jenis Penelitian}

Jenis penelitian ini adalah penelitian deskriptif kualitatif. Hal-hal yang dideskripsikan dalam penelitian ini adalah jenis-jenis kesalahan yang dilakukan siswa serta persentase kesalahan siswa dalam menyelesaikan soal matematika pada materi himpunan. Pada penelitian ini, klasifikasi kesalahan siswa yang digunakan ialah kesalahan siswa menurut Kiat (2005) yaitu :

1. Kesalahan konseptual, indikator yang digunakan yaitu: a) kesalahan karena kurang memahami konsep yang terkait dengan masalah yang diberikan; b) kesalahan karena tidak mampu menentukan hubungan yang terlibat dalam masalah

2. Kesalahan Prosedural, indikator yang digunakan yaitu: kesalahan karena tidak mampu melakukan manipulasi berupa memilih rumus yang sesuai untuk menyelesaikan masalah yang ada

3. Kesalahan Teknis, indikator yang digunakan yaitu: a) Kesalahan karena kurangnya pengetahuan konten matematika dalam topik lain; b) Kesalahan kecerobohan dalam menyelesaikan soal yang diberikan.

\section{Waktu dan Subjek Penelitian}

Penelitian dilakukan pada semester ganjil tahun ajaran 2020/2021 dengan subjek penelitian dipilih secara acak sebanyak 10 orang siswa kelas VII MTsS Mahadurrokan Sekeladi di Rokan Hilir.

\section{Instrumen Penelitian}

Instrumen yang digunakan dalam penelitian ini adalah soal tes tertulis berupa uraian yang terdiri dari 5 soal pada materi himpunan kelas VII dengan kompetensi dasar sebagai berikut:

3.4 Menjelaskan himpunan, himpunan bagian, himpunan semesta, himpunan kosong, komplemen himpunan, dan melakukan operasi biner pada himpunan menggunakan masalah kontekstual.

3.5 Menyelesaikan masalah kontekstual yang berkaitan dengan himpunan, himpunan bagian, himpunan semesta, himpunan kosong, komplemen himpunan dan operasi biner pada himpunan. Instrumen tes yang digunakan dalam penelitian ini dapat dilihat pada Tabel 1 di bawah ini:

Tabel 1. Instrumen Tes Soal Uraian

\begin{tabular}{|c|c|l|}
\hline Soal & $\begin{array}{c}\text { Indikator Pencapaian } \\
\text { Kompetensi }\end{array}$ & \multicolumn{1}{|c|}{ Soal } \\
\hline \multirow{2}{*}{1} & $\begin{array}{c}\text { Menjelaskan cara } \\
\text { menyatakan suatu } \\
\text { himpunan dengan } \\
\text { mendaftarkan anggotanya } \\
\text { dari masalah kontekstual. }\end{array}$ & $\begin{array}{l}\text { Diketahui P adalah himpunan nama-nama bulan dalam setahun } \\
\text { dan Q adalah himpunan nama-nama bulan yang berawalan } \\
\text { huruf J. Sajikanlah kedua himpunan diatas dengan } \\
\text { mendaftarkan anggotanya! }\end{array}$ \\
\hline \multirow{2}{*}{2} & $\begin{array}{c}\text { Menentukan himpunan } \\
\text { semesta dan himpunan } \\
\text { bagian dari masalah } \\
\text { kontekstual }\end{array}$ & $\begin{array}{l}\text { Anto, Andi dan Ikhwan sedang berada di sebuah kantin } \\
\text { sekolah yang menyediakan berbagai menu makanan dan } \\
\text { minuman. Anto memesan makanan kesukaanya yaitu nasi } \\
\text { goreng, kerupuk dan teh es. Andi memesan sate, gorengan dan } \\
\text { jus pokat. Sementara Ikhwan memesan makanan yaitu soto, } \\
\text { kerupuk dan air mineral. Tentukan: }\end{array}$ \\
\hline
\end{tabular}




\begin{tabular}{|c|c|c|}
\hline & & $\begin{array}{l}\text { a. Himpunan semesta dari permasalahan di atas! } \\
\text { b. Semua himpunan bagian dari masalah tersebut! }\end{array}$ \\
\hline 3 & $\begin{array}{l}\text { Menenentukan hasil } \\
\text { operasi himpunan dari } \\
\text { masalah kontekstual }\end{array}$ & $\begin{array}{l}\text { Di wilayah RT } 05 \text { ada penduduk yang memelihara hewan } \\
\text { ternak. Hewan ternak tersebut antara lain adalah kuda, sapi, } \\
\text { kambing, ayam, bebek, kerbau, dan burung. Pak Harno dan } \\
\text { Pak Ahmad adalah penduduk RT 05. Pak Harno mempunyai } \\
\text { hewan ternak ayam, burung, dan kerbau. Pak Ahmad } \\
\text { mempunyai hewan ternak bebek, kambing, dan burung. } \\
\text { Tentukanlah jawaban berikut dengan menulis simbol dari } \\
\text { operasi himpunan yang ditanya (gabungan, irisan, selisih atau } \\
\text { komplemen) serta daftarkan anggotanya: } \\
\text { a. Hewan ternak Pak Harno dan Pak Ahmad! } \\
\text { b. Hewan ternak Pak Harno atau Pak Ahmad! } \\
\text { c. Hewan ternak Pak Harno yang tidak diternak Pak } \\
\text { Ahmad! } \\
\text { d. Hewan ternak di wilayah RT } 05 \text { yang bukan milik Pak } \\
\text { Ahmad! }\end{array}$ \\
\hline 4 & $\begin{array}{l}\text { Menyelesaikan masalah } \\
\text { kontekstual yang berkaitan } \\
\text { dengan himpunan semesta }\end{array}$ & $\begin{array}{l}\text { Sebuah Pasar terdiri dari } 35 \text { pedagang yang menjual sayur, } 15 \\
\text { pedagang menjual ikan, } 7 \text { pedagang menjual sayur dan ikan. } \\
\text { Dan } 12 \text { pedagang yang tidak menjual sayur dan ikan. Berapa } \\
\text { banyakkah pedagang di pasar tersebut? }\end{array}$ \\
\hline 5 & $\begin{array}{l}\text { Menyelesaikan masalah } \\
\text { kontekstual yang berkaitan } \\
\text { dengan operasi himpunan }\end{array}$ & $\begin{array}{l}\text { Dalam suatu kelas terdiri dari } 35 \text { siswa, } 16 \text { siswa gemar } \\
\text { bermain catur, } 15 \text { siswa gemar bermain tenis meja, dan } 10 \\
\text { siswa gemar kedua olahraga tersebut. } \\
\text { a. Buatlah diagram venn dari permasalahan tersebut! } \\
\text { b. Berapa banyak siswa yang tidak gemar catur dan tenis } \\
\text { meja? }\end{array}$ \\
\hline
\end{tabular}

Setelah instrumen disusun, selanjutnya dilakukan analisis kualitas instrumen. Analisis kualitas instrumen bertujuan untuk mengetahui baik atau tidaknya instrumen yang digunakan. Hasil analisis kualitas intrumen yang diperoleh disajikan pada Tabel 2.

Tabel 2. Rekapitulasi Hasil Analisis Kualitas Instrumen

\begin{tabular}{|c|c|c|c|c|}
\hline No. & Validitas & Reliabilitas & Daya Pembeda & Tingkat Kesukaran \\
\hline 1 & Valid & & Cukup & Mudah \\
\hline 2 & Valid & \multirow{4}{*}{ Sedang } & Baik & Sukar \\
\cline { 4 - 4 } \cline { 4 - 4 } & Valid & Baik & Sukar \\
\hline 4 & Valid & Cukup & Sukar \\
\hline 5 & Valid & & Baik & Mudah \\
\cline { 4 - 5 } & & &
\end{tabular}

Berdasarkan hasil perhitungan uji validitas instrumen yang dilakukan, diperoleh bahwa instumen yang digunakan valid untuk semua soal. Hasil uji reliabilitas yang diperoleh ialah 0,65 yang berada pada interval $0,40 \leq r<0,70$, maka instrumen soal yang diberikan memiliki korelasi yang sedang dengan interpretasi reliabilitasnya cukup tetap atau cukup baik. Untuk daya pembeda instrumen diperoleh bahwa daya pembeda "cukup" untuk soal nomor 1 dan 4, dan daya pembeda "baik" untuk soal nomor 2, 3 dan 5. Tingkat kesukaran instrumen diperoleh bahwa untuk soal nomor 1 dan 5 termasuk kategori mudah, dan untuk soal nomor 2, 3 dan 4 termasuk kategori sukar. Dengan demikian, instrumen tes yang digunakan layak digunakan. 


\section{Teknik Pengumpulan Data}

Teknik pengumpulan data dalam penelitian ini adalah menggunakan teknik pengukuran dengan alat pengumpul data yaitu tes soal tertulis yang berisi 5 soal uraian pada materi himpunan. Soal uraian yang diberikan kepada siswa bertujuan untuk mengetahui letak dan jenis kesalahan yang dilakukan oleh siswa untuk dideskripsikan sesuai dengan jenis kesalahannya. Setelah jawaban siswa dikoreksi, kemudian dipilih dan dikelompokkan jawaban yang salah sesuai dengan jenis kesalahannya. Contoh jawaban siswa yang terdapat kesalahan kemudian disajikan dalam bentuk gambar, dan dideskripsikan letak kesalahannya dan dipersentasekan berdasarkan total kesalahan yang dilakukan siswa.

\section{Teknik Analisis Data}

Teknik analisis data yang dilakukan yaitu: 1) mengoreksi hasil jawaban siswa; 2) mengindentifikasi, mengklasifikasi, dan menganalisis kesalahan konseptual, prosedural dan teknis yang dilakukan oleh siswa dalam menjawab soal; 3) menghitung persentase kesalahan pada tiap butir soal untuk setiap jenis kesalahan; 4) data yang telah dihitung akan di analisis secara deskriptif; 5) membuat kesimpulan. Untuk persentase kesalahan siswa menggunakan rumus:

$$
P_{i}=\frac{n_{i}}{N} \times 100 \%
$$

Keterangan:

$P_{i}=$ Persentase kesalahan siswa kategori i

$n_{i}=$ Jumlah kesalahan siswa kategori i pada semua soal

$\mathrm{N}=$ Jumlah kesalahan yang terjadi

Setelah persentase kesalahan diperoleh, selanjutnya membuat kesimpulan dari persentase kesalahan siswa untuk menentukan tingkat kesalahan yang dilakukan siswa dengan menggunakan kriteria Muhammad Ali (dalam Anggraini \& Kartini, 2020), kriteria tersebut tercantum pada Tabel 3.

Tabel 3. Kriteria Tingkat Kesalahan Siswa

\begin{tabular}{|c|c|}
\hline Persentase & Kriteria \\
\hline $0 \% \leq p<20 \%$ & Sangat Rendah \\
\hline $20 \% \leq p<40 \%$ & Rendah \\
\hline $40 \% \leq p<60 \%$ & Cukup \\
\hline $60 \% \leq p<80 \%$ & Tinggi \\
\hline $80 \% \leq p<100 \%$ & Sangat Tinggi \\
\hline
\end{tabular}

\section{HASIL DAN DISKUSI}

Hasil olah data yang diperoleh dari 10 orang siswa kelas VII MTsS Mahadurrokan Sekeladi di Rokan Hilir pada materi himpunan diperoleh nilai rata-rata keseluruhan siswa ialah 35 dengan nilai tertinggi ialah 79 dan nilai terendah ialah 5. Dapat diketahui bahwa nilai rata-rata siswa masih jauh dibawah kriteria ketuntasan minimal (KKM) yaitu 70. Hal ini menunjukkan bahwa, siswa masih mengalami kesulitan dalam menjawab soal dengan benar. Masih dijumpai berbagai bentuk kesalahan. Total kesalahan yang dilakukan siswa ialah sebanyak 45 kesalahan. Kesalahan konseptual ada 
sebanyak 31 kesalahan, kesalahan prosedural sebanyak 4 kesalahan dan kesalahan teknis ada sebanyak 9 Persentase kesalahan yang dilakukan siswa pada materi himpunan dapat dilihat pada Gambar 1.

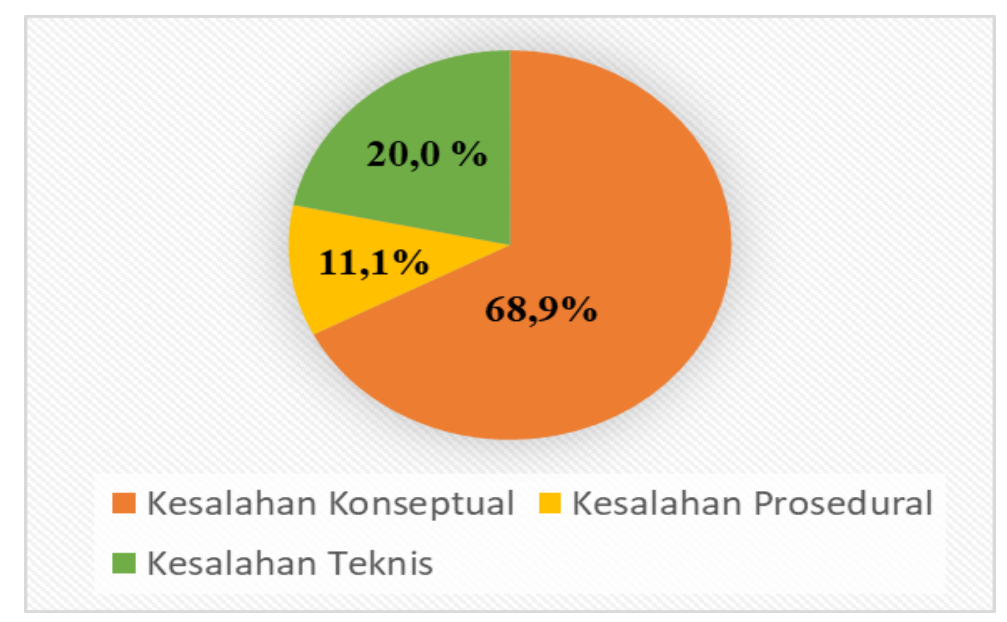

Gambar 1. Persentase Kesalahan Siswa

\section{Kesalahan Konseptual}

Kesalahan konseptual merupakan kesalahan yang paling banyak dilakukan siswa dengan persentase kesalahan sebesar 68,9\% dengan total kesalahan sebanyak 31 kesalahan, sehingga dapat disimpulkan bahwa tingkat kesalahan konseptual termasuk kategori "Tinggi". Besarnya persentase kesalahan konseptual yang terdapat pada setiap indikator dapat dilihat pada Gambar 2 berikut ini:

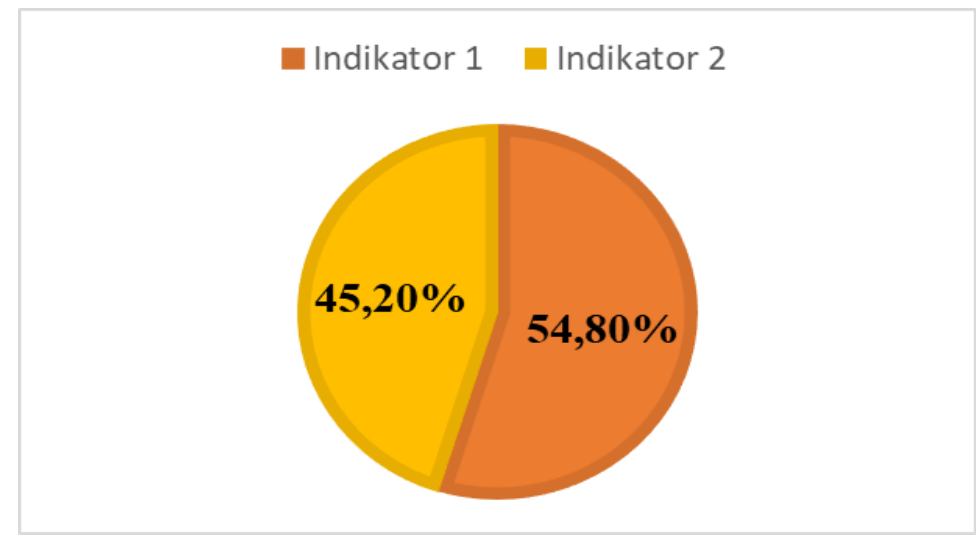

Gambar 2. Persentase Kesalahan Konseptual

Indikator 1: Kesalahan Karena Kurang Memahami Konsep Terkait dengan Masalah yang Diberikan

Kesalahan konseptual pada indikator 1 merupakan kesalahan yang paling banyak dilakukan yaitu sebesar 54,8 \%. Berikut disajikan Tabel 4 yang memperlihatkan kesalahan konseptual pada indikator 1 yang dilakukan siswa pada setiap butir soal: 
Tabel 4. Kesalahan Konseptual Indikator 1

\begin{tabular}{|c|c|c|c|c|c|}
\hline \multirow{2}{*}{$\begin{array}{c}\text { Nama } \\
\text { Siswa }\end{array}$} & \multicolumn{5}{|c|}{ Kesalahan Karena Kurang Memahami Konsep yang Terkait dengan } \\
& \multicolumn{5}{|c|}{ Masalah } \\
\cline { 2 - 6 } & $\mathbf{1}$ & $\mathbf{2}$ & $\mathbf{3}$ & $\mathbf{4}$ & $\mathbf{5}$ \\
\hline S-1 & - & - & - & - & - \\
\hline S-2 & - & - & - & - & - \\
\hline S-3 & - & $\sqrt{ }$ & - & - & - \\
\hline S-4 & - & $\sqrt{ }$ & $\sqrt{ }$ & - & - \\
\hline S-5 & - & - & $\sqrt{ }$ & $\sqrt{ }$ & $\sqrt{ }$ \\
\hline S-6 & $\sqrt{ }$ & $\sqrt{ }$ & - & $\sqrt{ }$ & - \\
\hline S-7 & - & $\sqrt{ }$ & $\sqrt{ }$ & $\sqrt{ }$ & $\sqrt{ }$ \\
\hline S-8 & - & $\sqrt{ }$ & - & - & - \\
\hline S-9 & - & $\sqrt{ }$ & $\sqrt{ }$ & - \\
\hline S-10 & - & - & - & - & - \\
\hline
\end{tabular}

Berdasarkan Tabel 4, terlihat bahwa kesalahan konseptual pada indikator 1 terjadi pada setiap butir soal dengan total kesalahan yang dilakukan siswa sebanyak 17 kesalahan. Berikut disajikan Gambar 3 salah satu lembar jawaban siswa yang dikategorikan kesalahan konseptual indikator 1.

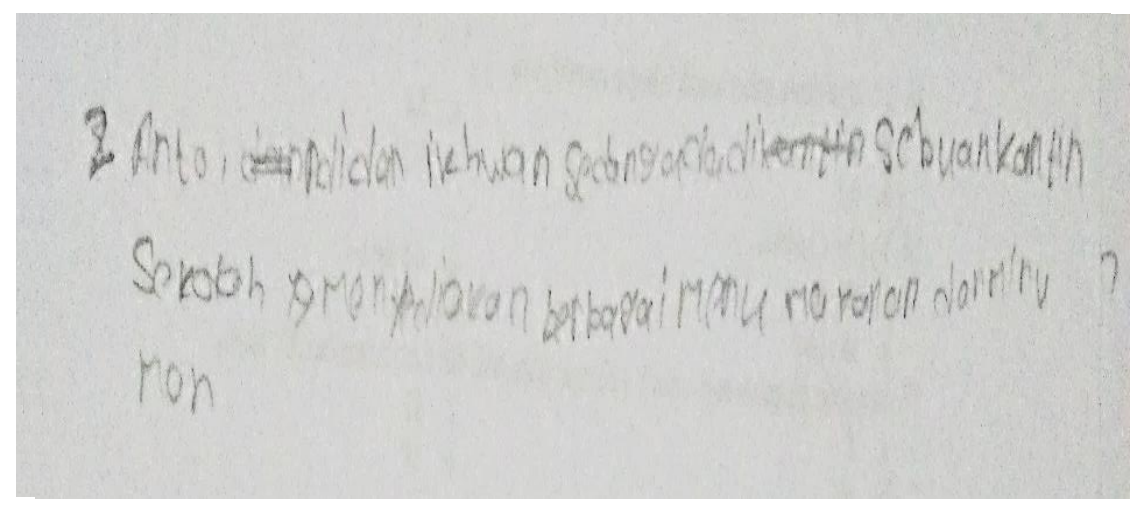

Gambar 3. Jawaban S-9 Nomor 2

Berdasarkan jawaban dari S-9 terhadap butir soal nomor 2, S-9 melakukan kesalahan konseptual indikator 1 yaitu tidak memahami konsep yang terkait dengan masalah yang diberikan. Perintah soal nomor 2 yaitu siswa diminta untuk menuliskan himpunan semesta dan himpunan bagian yang terdapat pada soal. Namun, S-9 hanya menyalin kembali beberapa penggalan kalimat dari soal tersebut yang bukan merupakan jawaban yang diharapkan.

Bentuk-bentuk kesalahan konseptual yang dilakukan siswa dalam penelitian ini yang dikategorikan pada indikator 1 yaitu: 1) Kesalahan dikarenakan tidak menjawab soal; 2) Kesalahan dikarenakan menuliskan kembali soal yang diberikan; 3) Kesalahan dikarenakan tidak menggunakan kurung kurawal dalam menyatakan himpunan; 4) Kesalahan dikarenakan tidak mampu menggunakan konsep himpunan, hal ini terlihat dari jawaban siswa yang hanya menuliskan hasil jawaban siswa tanpa menggunakan prosedur penyelesaian tertentu. Kesalahan karena tidak memahami konsep ini sejalan dengan pendapat Roselizawati (dalam Sulistio et al., 2019) kesalahan siswa dapat mencerminkan pemahamannya terhadap konsep matematika yang digunakan untuk menjawab soal matematika. Seperti yang ditemukan oleh Nurdiawan \& Zanthy (2019) siswa melakukan kesalahan 
dalam memahami konsep pada soal dikarenakan siswa tidak mengetahui apa yang sebenarnya ditanyakan pada soal sehingga siswa langsung menuliskan jawabannya tanpa prosedur penyelesaian.

\section{Indikator 2: Kesalahan Karena Tidak Mampu Menentukan Hubungan yang Terlibat dalam Masalah}

Kesalahan konseptual pada indikator 2 terjadi sebanyak 14 kesalahan dengan persentese kesalahan sebesar 45,2\%. Banyaknya kesalahan konsseptual yang dilakukan siswa pada indikator 2 dapat dilihat pada Tabel 5 berikut ini:

Tabel 5. Kesalahan Konseptual Indikator 2

\begin{tabular}{|c|c|c|c|c|c|}
\hline \multirow{2}{*}{ Nama Siswa } & \multicolumn{5}{|c|}{$\begin{array}{c}\text { Kesalahan Karena Tidak Mampu Menentukan Hubungan yang Terliba } \\
\text { dalam Masalah }\end{array}$} \\
\hline & 1 & 2 & 3 & 4 & 5 \\
\hline S-1 & $\sqrt{ }$ & $\sqrt{ }$ & - & - & - \\
\hline S-2 & $\sqrt{ }$ & $\sqrt{ }$ & - & - & - \\
\hline S-3 & - & - & $\sqrt{ }$ & - & - \\
\hline S-4 & $\sqrt{ }$ & - & - & $\sqrt{ }$ & - \\
\hline S-5 & $\sqrt{ }$ & $\sqrt{ }$ & - & - & - \\
\hline S-6 & - & - & $\sqrt{ }$ & - & - \\
\hline S-7 & - & - & - & - & - \\
\hline S-8 & $\sqrt{ }$ & - & $\sqrt{ }$ & $\sqrt{ }$ & - \\
\hline S-9 & - & - & - & - & - \\
\hline S-10 & - & - & - & $\sqrt{ }$ & - \\
\hline
\end{tabular}

Berdasarkan Tabel 5, dapat diketahui bahwa total kesalahan konseptual yang dilakukan siswa pada indikator 2 terhadap 5 butir soal ialah sebanyak 14 kesalahan yang terjadi pada hampir semua soal kecuali butir soal nomor 5. Kesalahan konseptual indikator 2 dapat dilihat pada lembar jawaban siswa berikut ini:

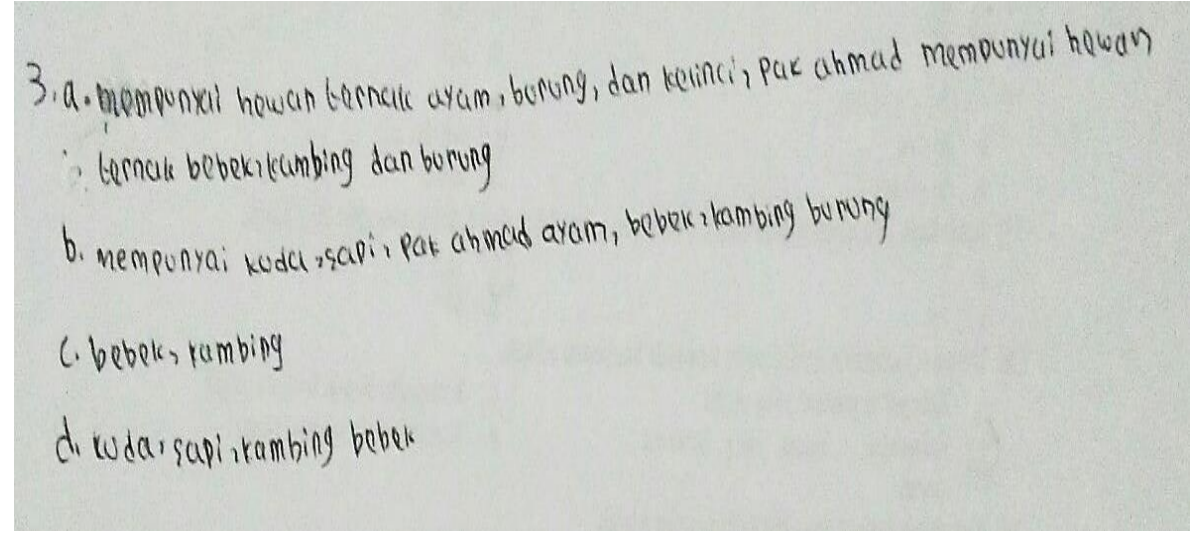

Gambar 4. Jawaban S-7 Nomor 3

Berdasarkan jawaban S-7 terhadap butir soal nomor 3 terilihat bahwa S-7 tidak mampu memahami konsep dari permasalahan yang ada, S-7 melakukan kesalahan dalam menentukan hasil operasi dari suatu himpunan yang diberikan, S-7 tidak mampu menentukan hubungan yang terlibat dari permasalahan yang diberikan, mana yang menggunakan konsep gabungan, irisan, selisih atau komplemen. Dengan demikian, S-7 dikategorikan melakukan kesalahan konseptual pada indikator 2. 
Bentuk-bentuk kesalahan konseptual lainnya dalam penelitian ini yang dikategorikan pada indikator 2 yaitu: 1) Tidak dapat membedakan konsep operasi himpunan dari permasalahan yang diberikan; 2) Tidak mendaftarkan anggota himpunan sesuai dengan himpunan yang diberikan pada soal, 3) Tidak menjelaskan mana himpunan semesta dan mana yang himpunan bagian dari jawaban yang ditulis. 4) Kesalahan dalam menentukan hubungan antara elemen-elemen yang diketahui pada soal. Kesalahan-kesalahan karena tidak mampu menentukan hubungan yang terlibat dalam masalah ini sejalan dengan pendapat Natsir et al. (2016) yang menyatakan bahwa apabila siswa salah dalam memahami dan menerapkan konsep selisih himpunan, komplemen dan gabungan dalam menyelesaikan soal cerita himpunan maka kesalahan tersebut merupakan kesalahan konsep. Kesalahan konseptual lainnya diungkapkan dalam penelitian Fauza et al. (2017) yang menjelaskan bahwa siswa memiliki kesalahan yang terletak pada representasi hubungan himpunan-hipunan ke dalam diagram venn. Siswa masih salah dalam menetapkan elemen himpunan-himpunanya, sehingga salah dalam menentukan jumlah anggotanya. Selanjutnya, penelitian yang dilakukan Rahayu \& Pujiastuti (2018) dengan soal yang sejenis pada soal nomor 2 dan 3 yakni mengklasifikasi obyekobyek menurut sifat-sifat tertentu sesuai dengan konsepnya, juga dijumpai bahwa siswa tidak dapat mengklasifikasi objek objek yang dimaksud.

\section{Kesalahan Prosedural}

Persentase kesalahan prosedural yaitu $11,1 \%$ dengan banyak kesalahan yang dijumpai yaitu 5 kesalahan dari total 45 kesalahan yang dilakukan siswa, sehingga dapat disimpulkan bahwa tingkat kesalahan prosedural termasuk kategori "Sangat rendah". Berikut disajikan Tabel 6 yang memperlihatkan kesalahan prosedural pada indikator yang digunakan yaitu kesalahan karena tidak mampu melakukan manipulasi berupa memilih rumus yang sesuai untuk menyelesaikan masalah yang ada pada setiap butir soal:

Tabel 6. Kesalahan Prosedural

\begin{tabular}{|c|c|c|c|c|c|}
\hline \multirow{3}{*}{ Nama Siswa } & \multicolumn{5}{|c|}{ Kesalahan Karena Tidak Mampu Melakukan Manipulasi Berupa } \\
& \multicolumn{4}{|c|}{ Memilih Rumus yang Sesuai untuk Menyelesaikan Masalah yang Ada } \\
\cline { 2 - 6 } & $\mathbf{1}$ & $\mathbf{2}$ & $\mathbf{3}$ & $\mathbf{4}$ & $\mathbf{5}$ \\
\hline S-1 & - & - & - & $\sqrt{ }$ & - \\
\hline S-2 & - & - & - & $\sqrt{ }$ & - \\
\hline S-3 & - & - & - & $\sqrt{ }$ & - \\
\hline S-4 & - & - & - & - & - \\
\hline S-5 & - & - & - & - & - \\
\hline S-6 & - & - & - & - & - \\
\hline S-7 & - & - & - & - & - \\
\hline S-8 & - & - & - & - & - \\
\hline S-9 & - & - & - & - & $\sqrt{ }$ \\
\hline S-10 & - & - & - & - & - \\
\hline
\end{tabular}

Berdasarkan Tabel 6, dapat diketahui bahwa total kesalahan prosedural yang dilakukan siswa sebanyak 5 kesalahan yang terjadi pada butir soal nomor 4 dan 5 . Kesalahan prosedural ini dapat dilihat pada lembar jawaban siswa berikut ini: 


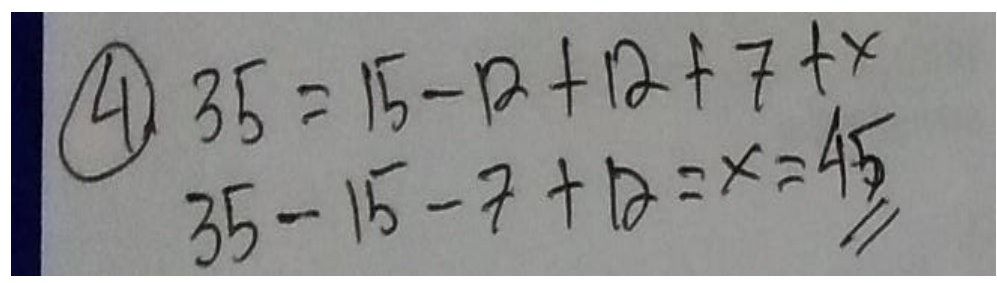

Gambar 5. Jawaban S-2 Nomor 4

Berdasarkan jawaban S-2 terhadap butir soal nomor 4 terilihat bahwa S-2 melakukan kesalahan dalam memilih rumus yang sesuai untuk menyelesaikan masalah yang diberikan, S-2 melakukan kesalahan dalam memanipulasi permasalahan, yang dipertanyakan ialah jumlah dari keseluruhan elemen yang diketahui (himpunan semesta), sedangkan S-2 menjadikan variabel x sebagai elemen dari himpunan semesta tersebut. Sehingga kesalahan ini dikategorikan kesalahan prosedural dikarenakan kesalahan dalam memanipulasi permasalahan kedalam bentuk model matematika.

Bentuk-bentuk kesalahan prosedural yang dijumpai dalam penelitian ini yang dikategorikan pada indikator kesalahan prosedural ialah: 1) Tidak dapat memanipulasi permasalahan kedalam bentuk model matematika; 2) Kesalahan dikarenakan langsung menjawab soal dengan perhitungan dengan menjumlahkan angka-angka yang diketahui. Hal ini sama yang terjadi pada penelitian yang dilakukan Natsir et al. (2016) dimana siswa tidak menyelesaikan soal dengan langkah-langkah pengerjaan yang benar, misalnya siswa menjawab soal langsung pada proses menghitung yaitu dengan menjumlahkan atau mengurangkan semua yang diketahui dalam soal. Sejalan dengan pendapat Lemer (dalam Sulistio et al., 2019) yang menyatakan bahwa beberapa kesalahan yang umum dalam mengerjakan soal matematika adalah kurang pengetahuan tentang simbol, penggunaan langkah yang keliru dan kesalahan dalam perhitungan.

\section{Kesalahan Teknis}

Kesalahan teknis merupakan kesalahan yang kedua paling banyak dilakukan siswa. Persentase kesalahan sebesar 20,0\% dengan total kesalahan sebanyak 9 kesalahan, sehingga dapat disimpulkan bahwa tingkat kesalahan teknis termasuk kategori "Rendah". Besarnya persentase kesalahan teknis yang terdapat pada setiap indikator dapat dilihat pada Gambar 6 berikut ini:

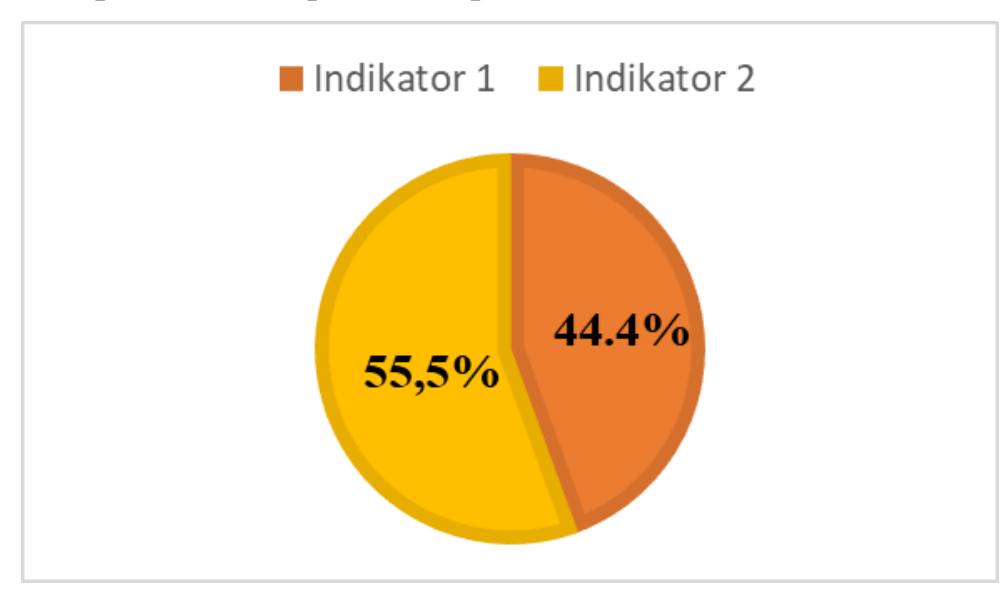

Gambar 6. Persentase Kesalahan Prosedural 


\section{Indikator 1: Kesalahan Karena Kurangnya Pengetahuan Konten Matematika Dalam Topik Lain}

Banyaknya kesalahan teknis yang dilakukan siswa pada indikator 1 dapat dilihat pada Tabel 7 berikut ini:

Tabel 7. Kesalahan Teknis Indikator 1

\begin{tabular}{|c|c|c|c|c|c|}
\hline \multirow{2}{*}{ Nama Siswa } & \multicolumn{6}{|c|}{ Kesalahan karena kurangnya pengetahuan konten matematika dalam } \\
& \multicolumn{5}{|c|}{ topik lain } \\
\cline { 2 - 6 } & $\mathbf{1}$ & $\mathbf{2}$ & $\mathbf{3}$ & $\mathbf{4}$ & $\mathbf{5}$ \\
\hline S-1 & - & - & $\sqrt{ }$ & - & - \\
\hline S-2 & - & - & $\sqrt{ }$ & - & - \\
\hline S-3 & - & - & - & - & - \\
\hline S-4 & - & - & - & - & - \\
\hline S-5 & - & - & - & - & - \\
\hline S-6 & - & - & - & - & - \\
\hline S-7 & - & - & - & - & - \\
\hline S-8 & - & - & - & - & - \\
\hline S-9 & - & - & - & - & - \\
\hline S-10 & - & - & - & - & - \\
\hline
\end{tabular}

Kesalahan teknis pada indikator 1 terdapat 4 kesalahan yang terjadi pada soal nomor 1, 3 dan 5 dengan persentase kesalahan sebesar 44,4\%. Kesalahan teknis pada indikator ini dapat dilihat pada gambar lembar jawaban siswa berikut ini:

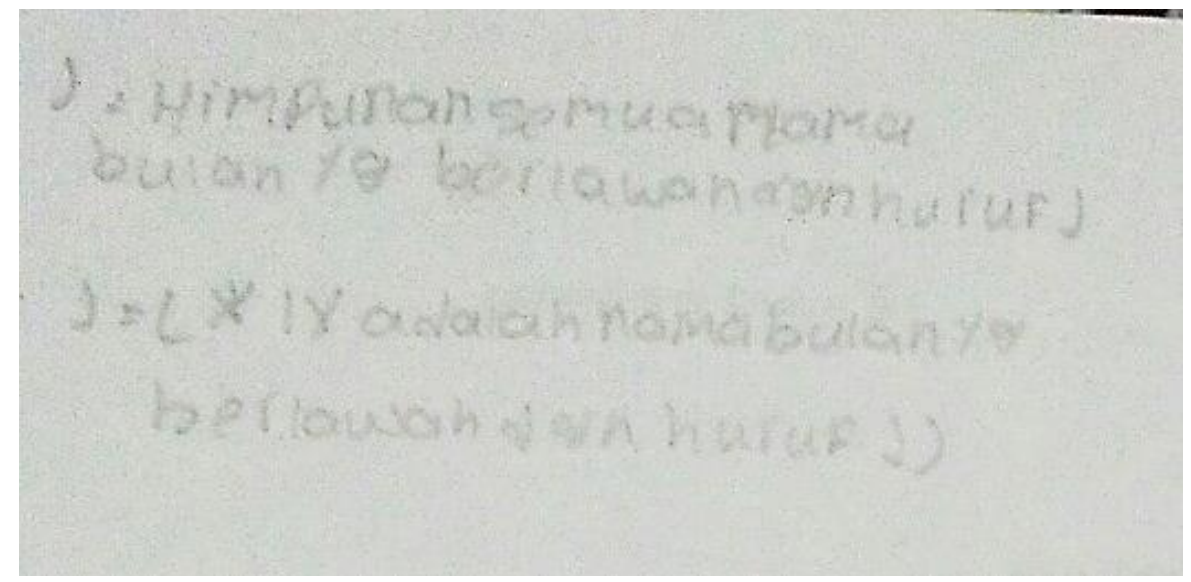

Gambar 7. Jawaban S-9 Nomor 1

Kesalahan teknis pada indikator 1 terjadi pada jawaban S-9 terhadap butir soal nomor 1 . Kesalahan pada jawaban S-9 dikategorikan kesalahan teknis pada indikator 1 dikarenakan S-9 menyelesaikan pekerjaan tidak sesuai dengan permintaan pada soal. Pada soal diminta untuk menyatakan himpunan dengan cara mendaftarkan anggotanya, namun S-9 menjawab dengan menggunakan notasi himpunan. Hal ini bisa dikarenakan S-9 tidak mengetahui bagaimana cara menyatakan himpunan selain menggunakan notasi himpunan. Sehingga ketika diminta untuk menyatakan himpunan dengan mendaftarkan anggotanya, siswa menjawab dengan menggunakan notasi himpuan.

Bentuk-bentuk kesalahan teknis yang dilakukan siswa dikategorikan pada indikator 1 ialah: 1) Tidak menjawab sesuai dengan permintaan soal; 2) Tidak sampai menjawab pertanyaan yang 
diberikan. Kesalahan ini serupa dengan kesalahan yang ditemui oleh Sulistio et al. (2019) dimana subjek dikategorikan ke dalam kesalahan ini dikarenakan subjek penelitian tidak mampu memahami tujuan dari permasalahan yang ada, sehingga subjek penelitian mampu mengerjakan tetapi tidak sampai menjawab pertanyaan yang diberikan. Dan Sundari et al. (2019) juga menemukan kesalahan yang serupa yakni siswa tidak mengakhiri apa yang sudah mereka tulis dikarenakan siswa tidak paham mengenai simbol-simbol beserta rumus dalam himpunan yang pada akhirnya membuat mereka tidak menuliskan hasil akhir yang ditanyakan dalam soal.

\section{Indikator 2: Kesalahan Dikarenakan Kecerobohan Dalam Menyelesaikan Soal yang Diberikan}

Persentase kesalahan teknis pada indikator 2 yaitu 55,5\% dengan banyak kesalahan yang dijumpai yaitu 5 kesalahan. Banyaknya kesalahan teknis yang dilakukan siswa pada indikator 2 dapat dilihat pada Tabel 8 berikut ini:

Tabel 8. Kesalahan Teknis Indikator 2

\begin{tabular}{|c|c|c|c|c|c|}
\hline \multirow{2}{*}{ Nama Siswa } & \multicolumn{5}{|c|}{ Kesalahan Dikarenakan Kecerobohan dalam Menyelesaikan Soal yang } \\
& \multicolumn{5}{|c|}{ Diberikan } \\
\cline { 2 - 6 } & $\mathbf{1}$ & $\mathbf{2}$ & $\mathbf{3}$ & $\mathbf{4}$ & $\mathbf{5}$ \\
\hline S-1 & - & - & - & - & $\sqrt{ }$ \\
\hline S-2 & - & - & - & - & $\sqrt{ }$ \\
\hline S-3 & - & - & - & - & $\sqrt{ }$ \\
\hline S-4 & - & - & - & - & - \\
\hline S-5 & - & - & - & - & - \\
\hline S-6 & - & - & - & - & - \\
\hline S-7 & - & - & - & - & - \\
\hline S-8 & - & - & - & - & $\sqrt{ }$ \\
\hline S-9 & - & - & - & - & - \\
\hline S-10 & - & - & - & - & $\sqrt{ }$ \\
\hline
\end{tabular}

Kesalahan teknis pada indikator 2 terjadi pada soal nomor 5. Berikut disajikan gambar lembar jawaban siswa yang termasuk kesalahan teknis indikator 2 :

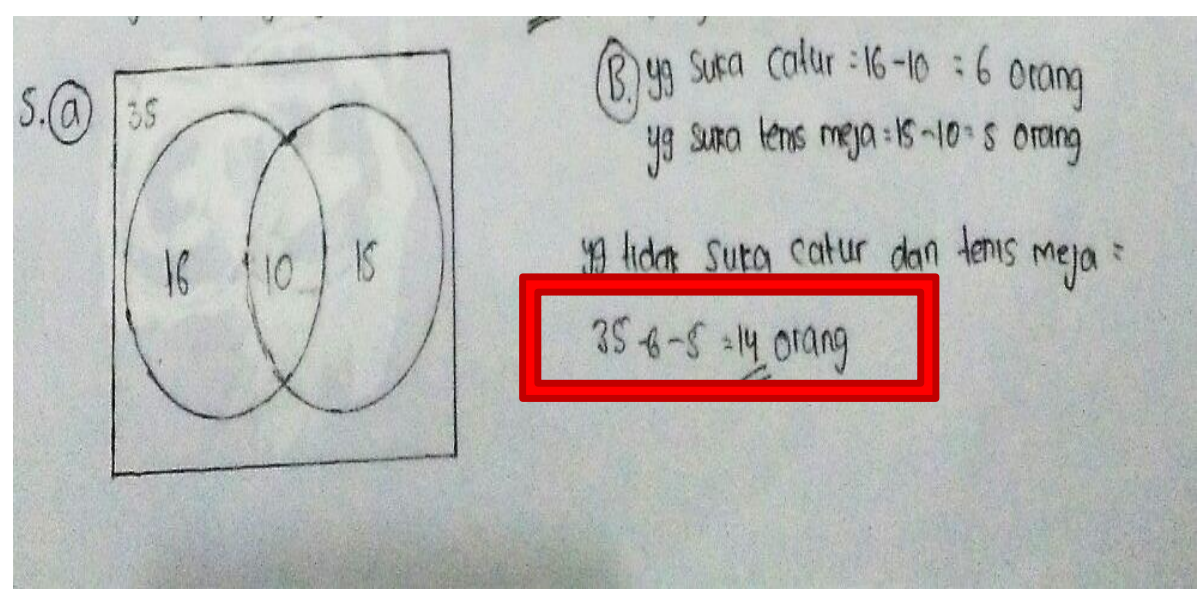

Gambar 8. Jawaban S-10 Nomor 5

Berdasarkan jawaban S-10 terhadap butir soal nomor 5, terlihat bahwa S-10 melakukan kesalahan pada bagian a dan b. Pada bagian a, dalam membuat gambar diagram venn dari 
permasalahan yang diberikan, S-10 melakukan kesalahan karena tidak menuliskan nama himpunan dalam gambar yang dibuatnya. Selain itu, Siswa juga salah dalam memasukkan nilai elemen dari masing-masing himpunan yang digambarnya, padahal berdasarkan jawaban siswa pada bagian $b$, siswa mengetahui berapa nilai elemen pada setiap himpunannya. Sedangkan pada bagian $b$, siswa mengalami kesalahan karena tidak menuliskan salah satu nilai elemen himpunan, padahal jawaban akhir yang diperoleh benar. Sehingga, kesalahan S-10 dikategorikan kesalahan teknis pada indikator 2 karena melakukan kecerobohan atau kurang teliti dalam menyelesaikan permasalahan yang diberikan.

Bentuk-bentuk kesalahan teknis yang dilakukan siswa dikategorikan pada indikator 1 ialah: 1) Tidak menuliskan nama himpunan pada gambar diagram venn yang dibuatnya; 2) Salah memasukkan nilai elemen himpunan yang digunakannya padahal ia mengetahui maksud soal (kurang teliti). Hal ini sejalan dengan Sulistio et al. (2019) yang menyatakan bahwa kesalahan teknis terjadi dikarenakan subjek kurang teliti dalam menentukan jumlah masukan yang harus ditulis pada diagram Venn padahal mereka sebenarnya sudah mengetahui maksud dari soal. Kesalahan yang sama juga diungkapkan oleh Patricia \& Zamzam (2020) yang menjelaskan bahwa siswa tidak menuliskan persyaratan elemen himpunan yang diberikan dikarenakan kurang teliti dalam mengerjakan sehingga ada bagian yang lupa ditulis.

Dari pemaparan hasil temuan ini dapat diketahui bahwa kesalahan konseptual terjadi pada setiap butir soal dengan persentase kesalahan konseptual dan tingkat kesalahan siswa yang berada pada kategori "Tinggi". Kesalahan konseptual yang paling banyak dilakukan siswa ialah kesalahan dalam menyatakan himpunan (seperti tidak menuliskan kurung kurawal, dan tidak menuliskan nama himpunan), kesalahan dalam memahami permasalahan yang berkaitan dengan himpunan semesta dan himpunan bagian, serta kesalahan dalam menggunakan konsep operasi himpunan. Kesalahankesalahan ini terjadi dikarenakan siswa masih belum memahami bagaimana cara menyatakan himpunan, simbol-simbol dalam himpunan, serta tidak dapat mengidentifikasi dan menggunakan konsep apa yang diperlukan dalam permasalahan yang diberikan. Hal ini sejalan dengan pendapat Sulistyaningsih \& Rakhmawati (2017) yang menjelaskan penyebab siswa melakukan kesalahan memahami masalah yaitu siswa kurang memahami maksud masalah yang diberikan karena kesulitan atau kendala mengubah kalimat cerita ke model matematika dan siswa terbiasa mengerjakan secara langsung pada proses perhitungannya tanpa menuliskan apa yang diketahui dan ditanyakan terlebih dahulu. Lebih lanjut, Hidayat \& Pujiastuti (2019) mengatakan bahwa kesalahan memahami soal dapat dilihat dari hasil pekerjaan siswa yaitu terdapat kata penting yang sering tidak dituliskan siswa. Kesalahan-kesalahan ini menujukkan bahwa pemahaman konseptual siswa terhadap konsep himpunan masih tergolong rendah. Sehingga untuk mengatasinya, guru diharapkan memberikan penekanan terhadap siswa mengenai bagian-bagian yang penting yang digunakan dalam konsep himpunan.

Kesalahan prosedural merupakan jenis kesalahan yang paling sedikit dilakukan siswa. Kesalahan prosedural terjadi pada butir soal nomor 4 dan 5 saja. Hal ini sejalan dengan tingkat kesalahan siswa yang berada pada kategori "Sangat rendah". Kesalahan prosedural yang dilakukan 
siswa ialah siswa belum mampu memanipulasi permasalahan ke dalam bentuk model matematika dan siswa salah dalam perhitungan. Kesalahan ini terjadi dikarenakan siswa kurang memahami maksud dari soal, sehingga salah dalam menggunakan informasi yang dibutuhkan dalam prosedur penyelesaian masalah yang tepat. Seperti yang diungkapkan oleh Nurdiawan \& Zanthy (2019) siswa salah menangkap informasi yang ada di soal sehingga siswa langsung menuliskan dan menghitung apa saja yang diketahui pada soal tanpa memilah terlebih dahulu apa yang dibutuhkan. Selain itu, kesalahan ini terjadi juga dikarenakan subjek belum memahami cara mengubah ke dalam bentuk model matematika dan belum memahami cara menyelesaikan soal (Fauza et al., 2017). Salah satu cara yang dapat dilakukan guru ialah dengan memberikan contoh menyelesaikan masalah matematika terkait materi himpunan lebih sering dalam proses belajar mengajar di kelas dengan harapan agar siswa dapat terbiasa dalam menyelesaikan masalah matematika pada materi himpunan (Mursalina et al., 2019).

Kesalahan teknis berada pada tingkat kesalahan kategori "Rendah" dengan kesalahan yang terjadi pada butir soal nomor 1,3 dan 5. Kesalahan yang sering terjadi pada kesalahan teknis ialah kesalahan dikarenakan kurang teliti dan tidak menyelesaikan soal sesuai dengan permintaan soal. Kesalahan ini terjadi dikarenakan siswa kurang teliti dalam memahami soal atau kurangnya pengetahuan siswa terhadap konten yang diharapkan pada soal, sehingga siswa menjawab sesuai dengan pengetahuannya saja. Hal ini sependapat dengan Sundari et al. (2019) yang mengatakan bahwa siswa menjawab tidak sesuai dengan permintaan soal disebabkan karena kesalahan siswa diawal dalam menerjemahkan dan menyelesaikan soal cerita kedalam model matematika. Dan menurut Adilistiyo \& Slamet (2017) faktor penyebab kesalahan dalam menyelesaikan soal himpunan adalah kurang telitinya siswa dan tergesa-gesa dalam menyeseaikan soal. Kesalahan ini dapat diantisipasi dengan seringnya guru untuk mengingatkan para siswa untuk teliti membaca soal dan memeriksa kembali hasil pengerjaan yang dilakukan agar dapat meminimalisir kesalahan yang dibuat oleh siswa (Farida, 2015).

\section{KESIMPULAN}

Berdasarkan analisis kesalahan siswa yang telah dilakukan, dapat disimpulkan bahwa kesalahan yang dilakukan siswa pada materi himpunan dapat diklasifikasikan ke dalam kesalahan konseptual, prosedural dan teknis. Kesalahan yang paling banyak dilakukan ialah kesalahan konseptual dengan persentase kesalahan sebesar 68,9\% yang menunjukkan bahwa tingkat kesalahan konseptual yang dilakukan siswa pada kategori "Tinggi”. Kesalahan konseptual yang dilakukan siswa ialah kesalahan dalam menyatakan himpunan, kesalahan dalam memahami permasalahan yang berkaitan dengan himpunan semesta dan himpunan bagian, serta kesalahan dalam menggunakan konsep operasi himpunan. Sedangkan kesalahan prosedural merupakan kesalahan yang paling sedikit dilakukan siswa dengan persentase kesalahan sebesar 11,1\% yang menunjukkan tingkat kesalahan pada kriteria "Sangat rendah". Kesalahan prosedural yang dilakukan siswa ialah kesalahan dalam memanipulasi 
permasalahan ke dalam bentuk model matematika dan kesalahan dalam perhitungan. Dan jenis kesalahan yang terakhir ialah kesalahan teknis dengan persentase kesalahan sebesar 20,0\% yang berada pada kriteria "Rendah". Kesalahan yang terjadi pada kesalahan teknis ialah kesalahan dikarenakan kecerobohan (kurang teliti) dan tidak menyelesaikan soal sesuai dengan permintaan soal. Dengan demikian, dapat simpulkan bahwa pemahaman konsep siswa terhadap konsep himpunan masih tergolong rendah, guru perlu memperhatikan pengetahuan siswa akan konsep materi himpunan dengan memberikan penekanan terhadap siswa mengenai bagian-bagian yang penting yang digunakan dalam konsep himpunan.

\section{UCAPAN TERIMA KASIH}

Ucapan terimakasih disampaikan kepada semua pihak yang telah ikut berkontribusi dalam penelitian ini sehingga penelitian terlaksana dengan baik dan hasilnya bisa dituangkan dalam tulisan ini dan diinformasikan kepada pembaca.

\section{REFERENSI}

Adilistiyo, M. E., \& Slamet, H. w. (2017). Analisis Kesalahan Siswa SMP Kelas VII dalam Menyelesaikan Soal Pada Materi Himpunan. In Doctoral dissertation, Universitas Muhammadiyah Surakarta (pp. 1-114).

Amelia, D., Susanto, S., \& Fatahillah, A. (2016). Analisis Hasil Belajar Matematika Siswa Pada Pokok Bahasan Himpunan Berdasarkan Ranah Kognitif Taksonomi Bloom Kelas VII-A di SMPN 14 Jember. Jurnal Edukasi, 2(1), 1-4.

Anggraini, Y. P., \& Kartini. (2020). Analisis Kesalahan Siswa dalam Menyelesaikan Soal Persamaan Kuadrat Pada Siswa Kelas IX SMPN 2 Bangkinang Kota. AXIOM: Jurnal Pendidikan Dan Matematika, 9(2), 210-223.

Dwidarti, U., Mampouw, H. L., \& Setyadi, D. (2019). Analisis Kesulitan Siswa dalam Menyelesaikan Soal Cerita pada Materi Himpunan. Jurnal Cendekia: Jurnal Pendidikan Matematika, 3(2), 315-322.

Farida, N. (2015). Analisis Kesalahan Siswa SMP Kelas VIII dalam Menyelesaikan Masalah Soal Cerita Matematika. Aksioma: Jurnal Pendidikan Matematika FKIP Universitas Muhammadiyah Metro, 4(2), 2015.

Fauza, A., Sinaga, N. Y., \& Mukasyaf, F. (2017). Analisis Kesalahan Siswa dalam Menyelesaikan Soal pada Materi Himpunan di Kelas VII-A SMP Swasta Imelda Medan. Seminar Nasional Matematika UNIMED,

129-135.

https://proceedings.radenintan.ac.id/index.php/pspm/article/view/30

Haryadi, R., \& Nurmaningsih, N. (2019). Analisis Kesalahan Mahasiswa dalam Menyelesaikan Soal Persamaan Garis Lurus. Jurnal Elemen, 5(1), 1-11.

Hidayat, D. W., \& Pujiastuti, H. (2019). Analisis Kesalahan Siswa dalam Menyelesaikan Masalah Matematis pada Materi Himpunan. Jurnal Analisa, 5(1), 59-67.

Kiat, S. E. (2005). Analysis of Students' Difficulties in Solving Integration Problems. The Mathematics Educator, 9(1), 39-59. http://math.nie.edu.sg/ame/matheduc/journal/v9_1/v91_39.aspx

Lenterawati, B. S., Pramudya, I., \& Kuswardi, Y. (2018). Analisis Kesalahan Berdasarkan Tahapan Kastolan dalam Menyelesaikan Soal Cerita Sistem Persamaan Linear Dua Variabel Ditinjau dari Gaya Berpikir Siswa Kelas VIII SMP Negeri 19 Surakarta Tahun Pelajaran 2018/2019. Jurnal 
Pendidikan Matematika Dan Matematika (JPPM), 2(6), 471-482.

Listiana, A. D., \& Sutriyono. (2018). Analisis Kesalahan Siswa dalam Menyelesaikan Soal Cerita Pada Materi Himpunan Bagi Siswa Kelas VII SMP Semester I Tahun Ajaran 2016/2017. Jurnal Pendidikan Berkarakter, 1(1), 60-65.

Mauliandri, R., \& Kartini. (2020). Analisis Kesalahan Siswa Menurut Kastolan dalam Menyelesaikan Soal Operasi Bentuk Aljabar Pada Siswa SMP. AXIOM: Jurnal Pendidikan Dan Matematika, 9(2), 107-123.

Mursalina, A., Sujatmiko, P., \& Kurniawati, I. (2019). Analisis Kesulitan Menyelesaikan Masalah Matematika Berdasarkan Newman's Error Analysis Pada Materi Himpunan Ditinjau Dari Gaya Kognitif Siswa (Penelitian dilakukan di Kelas VII SMP Negeri 16 Surakarta). Jurnal Pendidikan Matematika Dan Matematika (JPMM), 3(3), 310-323.

Natsir, N., Tandiayuk, M. B., \& Karniman, T. S. (2016). Profil Kesalahan Konseptual dan Prosedural Siswa dalam Menyelesaikan Soal Cerita Himpunan Di Kelas VII SMPN 1 Siniu. Jurnal Elektronik Pendidikan Matematika Tadulako, 3(4), 440-453.

Ningsih, N., Hariyani, S., \& Fayeldi, T. (2019). Analisis Kesalahan Siswa dalam Menyelesaikan Soal Lingkaran Berdasarkan Kategori Watson. UNION: Jurnal Ilmiah Pendidikan Matematika, 7(2), 187-200.

Nurdiawan, R., \& Zanthy, L. S. (2019). Analisis kesalahan dalam menyelesaikan soal cerita pada materi himpunan berdasarkan tahapan newman. Journal On Education, 01(03), 128-134.

Patricia, F. A., \& Zamzam, K. F. (2020). Analisis Kesalahan Siswa Kelas 7 SMP dalam Penulisan Himpunan. Prosiding Seminar Nasional, IKIP Budi Utomo, 456-460.

Raharti, A. D., \& Yunianta, T. N. H. (2020). Identifikasi Kesalahan Matematika Siswa SMP Berdasarkan Tahapan Kastolan. Journal of Honai Math, 3(1), 77-100.

Rahayu, Y., \& Pujiastuti, H. (2018). Analisis Kemampuan Pemahaman Matematis Siswa SMP pada Materi Himpunan: Studi Kasus di SMP Negeri 1 Cibadak. Symmetry: Pasundan Journal of Research in Mathematics Learning and Education, 3(2), 93-102.

Ratnasari, S., \& Setiawan, W. (2007). Analisis kesulitan belajar siswa pada materi himpunan. Journal On Education, 01(02), 473-479.

Sulistio, W., Muhsetyo, G., \& Qohar, A. (2019). Klasifikasi Kesalahan Siswa Kelas VII Tentang Materi Himpunan. Jurnal Pendidikan: Teori, Penelitian, Dan Pengembangan, 4(6), 706-711.

Sulistyaningsih, A., \& Rakhmawati, E. (2017). Analisis Kesalahan Siswa Menurut Kastolan Dalam Pemecahan Masalah Matematika. Seminar Matematika Dan Pendidikan Matematika Uny, 19(2), 123-130.

Sundari, R., Andhany, E., \& Dur, S. (2019). Analisis Kesulitan Siswa dalam Menyelesaikan Soal Cerita Materi Himpunan ditinjau dari Tahapan Newman Pada Kelas VII MTs Negeri Hamparan Perak T.A 2017/2018. AXIOM: Jurnal Pendidikan Dan Matematika, 8(2), 187-194.

Wibawa, H. (2017). Analisis Pemahaman Konsep Matematika Siswa dalam Menyelesaikan Soal Materi Himpunan Berdasarkan Taksonomi Solo (Structure Of Observed Learning Outcomes) pada Siswa Kelas VII SMP Negeri 2 Baki. In Universitas Muhammadiyah Surakarta (pp. 1-16).

Yuanita, P., \& Solfitri, T. (2014). Analisis kesalahan siswa menyelesaikan soal matematika materi pokok bangun datar segiempat pada pelaksanaan pembelajaran kooperatif pendekatan struktural think pair square (TPS). Al-Khwarizmi: Jurnal Pendidikan Matematika Dan Ilmu Pengetahuan Alam, 2(2), 127-142. 